\title{
Agency, Institutions and Regional Resilience: An Approach from the Basque Region
}

Edurne Magro, Elvira Uyarra, and Jesus M. Valdaliso

\section{INTRODUCTION}

Resilience is a phenomenon that has been widely studied in the context of organizations and, in this field, it is normally understood as the capacity to return to a previous 'status quo' after a disturbance. However, in the last decade resilience has been applied to regions as a means of understanding economic development.

\footnotetext{
E. Magro $(\bowtie)$

Orkestra-Basque Institute of Competitiveness and Deusto Business School, University of Deusto, San Sebastián, Spain

e-mail: edurne.magro@orkestra.deusto.es

E. Uyarra

Alliance Manchester Business School, University of Manchester, Manchester, UK

e-mail: Elvira.Uyarra@manchester.ac.uk

J. M. Valdaliso

The University of the Basque Country, Bilbao, Spain e-mail: jesusm.valdaliso@ehu.eus
}

(C) The Author(s) 2022

R. Pinheiro et al. (eds.), Towards Resilient Organizations and Societies, Public Sector Organizations, https://doi.org/10.1007/978-3-030-82072-5_11 
In the evolutionary economic geography literature, unlike the meaning of the concept in engineering, resilience does not imply a return to a previous equilibrium point or regional path but the ability of a system or a territory to resist, adapt, respond, recover and/or renew from a shock (Martin, 2012; Evans \& Karecha, 2014). Therefore, adaptation and evolution underline the concept of resilience. While adaptation could be seen as a process of change in regions due to unexpected shocks, resilience is the ability of those territories to deal with these changes on a continuous basis (Evenhuis, 2017a). As a consequence, in order to observe and analyse regional resilience it is necessary to adopt a historical perspective as this ability should be seen in multiple episodes (Evenhuis, 2017a).

While the importance of institutions, policies and agency for shaping regional resilience has been acknowledged in recent literature (Boschma, 2015; Bristow \& Healy, 2014), this relationship remains underexplored, especially when adopting a historical perspective (Henning, 2019). This is mainly due to resilience being a complex and multifaceted concept, that goes beyond the idea of adaptation. Thus, Boschma (2015) distinguishes between adaptation and adaptability processes, the former related to maintaining regional paths and the latter referred to the creation of new regional growth paths. This distinction is important in order to understand regional resilience as each process relates to very different types of policy rationales and attitudes of the actors involved, namely reactivity and proactivity (Bristow \& Healy, 2014).

The notion of shock or disturbance is also another important aspect to understand the concept of resilience, as it can be referred either to macroeconomic fluctuations such as economic recessions or structural changes in the economy (such as deindustrialization). The evolutionary concept of resilience is more adequate to understand how regions respond to the latter ones but also useful for understanding the mechanisms of change delivered to cope with economic crises (Evenhuis, 2017a). Therefore, this chapter will deepen into the different mechanisms of change for a regional economy to develop resilience through exploring the role of policy and agency in the two process of change: adaptation and adaptability. To do so, the chapter adopts a historical perspective to examine how the Basque Country, an old industrial region, has been able to resist, recover and renew itself after different shocks (economic and financial crises) and cope with structural changes in the last forty years.

The chapter first explores the link between resilience and regional policy, with a strong focus on industrial and innovation policies and the 
relevance of history for understanding regional development. Second, the chapter presents different types of agency that shape institutions and condition resilience. All these concepts will be explored in depth in a regional case that discusses how policy paths relate to different types of regional resilience and disentangle the role of agency in the processes of change.

\section{Regional Resilience And the Role of Policies}

In evolutionary economic geography, regional resilience refers to the ability of a region to deal with changes on a continuous basis (Evenhuis, 2017a). Resilience is therefore seen as a dynamic, path-dependent process. This implies that previous regional growth paths condition future resistance to, and recovery from, a shock as well as shape future available paths (Boschma, 2015; Martin, 2012; Martin \& Sunley, 2015; Martin et al., 2016; Simmie \& Martin, 2010; Webber et al., 2018). The consideration of resilience as a capacity to deal with change needs to be investigated by adopting a historical perspective and by studying the multiple sequential adaptation episodes of a region to shocks, either market, competitive or environmental (Boschma, 2015; Evenhuis, 2017a; Henning, 2019).

Regional economic resilience is a complex and multi-faceted phenomenon. Martin (2010, 2012) distinguishes four dimensions of resilience: resistance (ability to resist a shock), recovery (speed and type of recovery after the shock), renewal (resumption of the pre-shock growth path) and reorientation (towards a new growth path). Recovery can be linked to the classic perspective of organizational resilience (Boinand \& Van Eeten, 2014) whereas reorientation is a concept which implicitly requires exploration. As to the factors that explain the resilience of regions, the literature has highlighted the following: the competitiveness and innovative propensity of regional firms, the regional economic structure and knowledge base, knowledge networks, labour market conditions, financial system and institutions such as policy measures, quality of government, governance and social capital (Boschma, 2015; Cortinovis et al., 2017; Crescenzi et al., 2016; Martin, 2012; Martin \& Sunley, 2015).

While institutional factors are acknowledged as important in explaining regional resilience, they are still relatively underexplored in the literature. Indeed, Martin et al. (2016) have found a great variation across regions in their resilience towards economic crises in Britain, something that they 
attribute to regional differences in economic structure and institutions. Although some authors argue that regional policies are not as important as productive specialization (Cuadrado \& Maroto, 2016; Eraydin, 2016), there is, in general, a broad agreement around the relative importance of institutions (among which policy measures can be highlighted) and agency in the resilience of regions.

Boschma (2015) makes a distinction between adaptation and adaptability processes underlying resilience, referring to situations where regions maintain previous economic specialization or shift towards new paths respectively. These concepts are not far from the seminal concepts of exploitation and exploration (March, 1991), or from those proposed by the literature of organizational resilience, which distinguishes two types of responses, anticipatory (static) and strategic (dynamic). The former aims at reducing the shock impact, the latter at maximizing recovery and renewal (Annarelli \& Nonino, 2016; Billington et al., 2017). The dichotomy proposed by Boschma can be linked to policy responses as it confronts two very different policy rationales and attitudes of the agents involved, namely reactivity and proactivity (Bristow \& Healy, 2014). Adaptation and adaptability are also associated to the different types of resilience needed in a region depending on the nature of the shock. Emergencies and macroeconomic fluctuations or recessions might require adaptation but structural changes of the regional economy such as changes in the industrial configuration need adaptability (Evenhuis, 2017a). Nevertheless, these shocks are never isolated as for example economic and financial recessions necessarily affect industrial configurations and regional competitiveness. Therefore, adaptation and adaptability are not necessarily opposed, they can be complementary.

Adaptation and adaptability can be linked to different public policy interventions. A first and broad distinction has been made between reactive policy measures with the aim of supporting the adaptation and resistance to a certain shock, and proactive policy measures, aimed at transforming the existent economy and at creating new growth paths (e.g., measures to encourage adaptability) (Kakderi \& Tasopoulou, 2017). Policies that promote social and institutional learning, connectivity and flexibility make regional adaptation to a crisis easier. On the other hand, policies that foster diversity and related variety in the regional economy do not only help to reduce the risk of lock-in but also open up new development paths for the region. It has also been accepted that a governance system with polycentric and multi-layered institutions, which 
promote public participation and collaboration between the different agents, increases regional resilience (Kakderi \& Tasopoulou, 2017). In line with Boschma (2015), Fratesi and Rodríguez-Pose (2016) argue that some factors, such as the workforce skills level or public policies, may provoke short-term adaptation and medium-term adaptability.

However, the literature on regional resilience still lacks a typology of policy measures and instruments. Among the reactive policy measures to adapt and resist, we could find macroeconomic policies (currency, monetary, labour costs) and restructuring policies (aids and subsidies to firms, early retirement schemes...). These policies are usually adopted as a (generally, quick) reaction towards a previous crisis or shock, and are expected to have a short-term effect on the whole regional economy, but they are not very effective on promoting a sustained regional economic development (Landabaso, 2012).

Among the proactive policy measures, we might point to horizontal framework policies (infrastructures, education, energy, internationalization), and to STI and cluster policies (Landabaso, 2012; Nauwelaers \& Wijtnes, 2008; Uyarra \& Ramlogan, 2012) that attempt to cope with some perceived structural problems or failures in the regional economy or to encourage processes of transformation, such as smart specialization strategies (Foray et al., 2012). In both cases, their expected effects will be observed in the mid to long-term.

We could say that 'reactive policies' (ex-post) attempt to face the urgent and unexpected needs of the region, whereas 'proactive policies' (ex-ante) attempt to address some changes seen as necessary, expected or anticipated. Regarding the effects of proactive policy measures on the adaptation and/or adaptability of the region, they would depend on the vertical priorities established. They can either reinforce the current economic specialization of the region, or promote an economic diversification, or a combination of both.

Crises and shocks may force the governments to allocate the existing resources towards urgent needs, e.g., the protection of certain groups from their negative consequences (unemployment, firms' closures...); but they can also trigger changes, in the sense that an adverse scenario may facilitate collaboration between agents towards a shared vision and a common goal. Indeed, some broad agendas and strategies for economic development were born in critical junctures of crisis and/or shocks (Valdaliso \& Wilson, 2015) as crisis may be windows of opportunity 
(Kingdon, 1984; Croenewegen \& van der Steen, 2007) or opportunity spaces (Grillitsch \& Sotarauta, 2018) for policy change.

Sometimes, policy measures can be framed in broader agendas for action that allocate and distribute resources according to different priorities and to the relative political power of every agent (Campbell, 2010; Mahoney \& Thelen, 2009). Agendas cannot be neutral, e.g., they tend to benefit some agents at the expenses of others (David, 2018). Agendas take usually the form of government programmes and are governmentled, although its leadership depends on the regional institutional context such as the system's governance and/or the quality of government. Pugalis et al. (2017) indicate that economic strategies, and therefore, agendas themselves, may reflect different dimensions or understanding of resilience, namely resistance, recovery or reorientation, which are link to what the authors conceptualize as conservative, resistant and evolutionary resilience.

\section{Regional Development and Path Dependence}

Kakderi and Tasopoulou (2017, p. 1438) argue that resilience must be studied 'within the context of longer run processes of change and policy options' in the region, which are path-dependent. Since Grabher's (1993) seminal work, path dependence has been a concept increasingly employed to explain regional development, initially to account for lock-in situations and, more recently, to explain the different evolutionary scenarios of regions, e.g., why change goes in a particular direction (Henning et al., 2013; Martin, 2010; Martin \& Sunley, 2006).

Historical institutionalism has devoted a great deal of attention to the role of path dependence and the mechanisms of continuity and change in social and political institutions and public policies (Campbell, 2010; Kay, 2006; Mahoney \& Thelen, 2009; Streeck \& Thelen, 2005). Politics is an activity subject to increasing returns and self-reinforcing effects, where the feedback effects of past policy choices shape and condition present and future policy developments (Kay, 2006; Pierson, 2004); and to vested interests of the agents involved, where policy change involves substantial technical, political and expectation costs (Gingrich, 2015; Kay, 2006). Policy measures are not simply short-term reactions to problems or crises. They are framed within shared mental maps, policy paradigms, agendas or discourses that have been previously adopted and maintained by policy communities, and are difficult to change (Baumgartner, 2013; 
Kay, 2006). Finally, agency and power shape the policy process. In the last resort, any policy adopted is a choice made by a government. But this choice is usually the outcome of a complex process of competition, cooperation and negotiation among the key actors involved that may have different interests and objectives (Baumgartner, 2013; Kay, 2006; Mahoney \& Thelen, 2009). Indeed, different mechanisms of institutional change can be highlighted from a bottom-up approach, in which actors can reinterpret existing institutional arrangements to a top-down approach in which arrangements are changed by powerful actors (i.e. governments, not only at regional level) (Evenhuis, 2017b). Institutional entrepreneurs, defined as coalitions of different actors (individual or collective) around a common goal (Bristow \& Healy, 2014; David, 2018; Martin, 2012), might be able to change institutional arrangements, which is a more powerful source for resilience.

Isaksen (2015) distinguishes among three types of regional paths. Path extension is a term which is related to path dependence. It refers to the incremental upgrading of existing industry in a region by maintaining existing technologies, which means adopting an exploitation approach (adaptive processes) (March, 1991). By their side, path renewal and path creation are more related to regional resilience as defined by Boschma (2015) and denote exploration and adaptability processes although to different extent. Path renewal takes place when industries shift towards new but related industries and therefore it is a concept linked to related variety (Neffke et al., 2011), which highlights that it is more likely that regional diversification takes place in related activities than in totally new ones. This would be the case of path creation, which constitutes a regional shift towards industries totally new for the region or completely new and therefore it reflects an exploration process (March, 1991). This would imply not only the establishment of new firms or industries but also the generation of new knowledge organizations and institutions, including policy. This case is not contemplated in the literature of related variety. Path creation and entrepreneurship are therefore two interrelated concepts, but not only referring to the creation of new industries and firms, also to the creation of new policies and institutions. Indeed, Kakderi and Tasopoulou (2017) argue and demonstrate with a case study that policies that promote social and institutional learning, flexibility and connectivity facilitate new path development and resilience. 


\section{AgENCY, INSTITUTIONAL ENTREPRENEURSHIP AND RESILIENCE}

Agency has been acknowledged in the recent literature as one of the key factors shaping the conditions for regional resilience (Boschma, 2015; Bristow \& Healy, 2014; Evenhuis, 2017a), including dedicated policies and institutional change. Policies are a form of institution in as much as they are rules for actors that 'can and need to be implemented and that are legitimate in that they will if necessary be enforced' (Streeck \& Thelen, 2005, p. 12). In order to understand resilience in regional economies, it is necessary to go beyond a narrow focus on macroeconomic performance of the region and take into account its individuals, organizations, industries and/or clusters, networks and institutions involving multiple agents (firms, workers, associations, RTOs, government and other organizations) (Boschma, 2015; Bristow \& Healy, 2014).

The importance of agency in regional resilience is part of a broader intellectual agenda inspired by the idea of institutional entrepreneurship (DiMaggio, 1988; Maguire et al., 2004) that has sought to understand how actors shape the emergence of new institutional arrangements. Institutional work is referred to in the literature as the purposive action of individuals and organizations aimed at creating, maintaining or disrupting existing institutions (Lawrence \& Suddaby, 2006, p. 215). The literature on institutional work conceives agency as a distributed and temporary embedded process of social engagement, whereby actors both reproduce and transform an environments' structure through the exercise of purpose, imagination and judgement (Emirbayer \& Mische, 1998).

Agency is distributed across a multiplicity of actors with different interpretive frameworks involved in different ways at different stages and embedded in networks and emerging pathways (Garud \& Karnøe, 2001, 2003). Actors are embedded in social structures and thus shaped by existing institutions, yet able to purposely deviate from them (Garud et al., 2010). It is also inter-temporal because it not only requires the 'capacity to imagine alternative possibilities', but also the ability 'to contextualize past habits and future projects within the contingencies of the moment' if existing institutions are to be transformed (Emirbayer \& Mische, 1998, p. 963). Related to this temporal dimension, three different elements of agency have been identified: iteration, practicalevaluation and projectivity (Battilana \& D'aunno, 2009; Emirbayer \& Mische, 1998). The first element (interaction) is oriented towards the 
past, and describes the 'selective reactivation by actors of past patterns of thought and action' (Battilana \& D'aunno, 2009, p. 46). The second (practical-evaluative) is the capacity of actors to make practical and normative judgements between alternative possible trajectories of action, in response to emerging demands, dilemmas and ambiguities of presently evolving situations. The third and final element (projective) involves an imaginative engagement with the future.

Embedded actors shape and configure new processes and mobilize the past to accomplish their objectives and to create new options for the future (Garud \& Karnøe, 2001). They connect the past with the future in the form of visions or expectations, in order to attract interest, mobilize resources, build political networks, develop technical capabilities and legitimize new practices (Croenewegen \& van der Steen, 2007; Steen, 2016; Uyarra et al., 2020). The term bricolage has been used to describe social actors purposefully bringing together resources and using what is at hand, and eventually creating the conditions for change and transformation (Campbell, 2010).

Agency, leadership and bricolage are present in regional development literature in the form of accounts of 'regional experimentalism' and synthesized in what Grillitsch and Sotarauta (2020) refer to the trinity of change agency driving regional industrial path development, namely innovative entrepreneurship, institutional entrepreneurship and place leadership. Innovative (Schumpeterian) entrepreneurs are those seeking to mindfully deviate from existing paths and create new paths. Institutional entrepreneurs seek to challenge existing norms, raise legitimacy and institutionalize alternative practices. Place-based leadership, or civic-leadership (Brooks, 2017), involves coordinating efforts and resources to enable new regional development opportunities.

Attention has been given for instance to the role of place-based leadership or place-renewing leadership in supporting resilience of places. Following Bristow and Healy (2014), it is a sort of collective agency that eventually might produce an agenda for action to anticipate and cope with external shocks and unanticipated events. Bailey et al. (2010, p. 462) define 'place-renewing leadership' as 'a form of public-private strategic leadership that empowers institutional or social forms of governance to absorb and adjust (pro-actively and re-actively) to path breaking economic change'. Bailey \& Berkeley (2014) examined the role of the West Midlands Regional Taskforce (WMRT) in contributing to the resilience of the West Midlands region in the UK, severely affected by the 
2008-2009 economic crisis. They argued that the WMRT played a key role in supporting two dimensions of resilience, in terms of recovery (e.g. by helping maintain key supply chain capacity in place during the crisis) and renewal (helping strategic firms upgrade into higher value activities and diversify into related sectors). Tomlinson and Branston (2014) analysed how the North Staffordshire ceramics industrial district was able to reverse a phase of 'long decline' through purposive adaptation and joint action by local actors, thus arguing that 'there is nothing inevitable about the trajectory of old industrial districts' (p. 502). Brooks (2017) similarly analysed the civic leadership exerted by the Local Enterprise Partnership of the Sheffield city region.

\section{Agency, Institutions and Resilience in THe Basque Country}

In order to explore the relationship between agency, institutions and regional resilience we employ a case study, with a longitudinal-e.g., historical- and holistic perspective, which fits well with the context-, place- and path-dependent nature of both resilience and the policy process (David, 2018; Flanagan \& Uyarra, 2016; Kakderi \& Tasopoulou, 2017; Kay, 2006; Navarro et al., 2014; Witt, 2003). Our analysis is based on a broad array of qualitative information: official policy programmes and agendas, reports, academic literature and interviews with the agents involved in the policy process conducted within different research projects developed from 2008 onwards.

The Basque Country is an old industrial region that has experienced a successful economic transformation over the last 30 years, driven by a highly interventionist regional government applying sustained industrial policies aimed at promoting science, technology and innovation, with a strong focus on industry. It is one of the most autonomous regions of both Spain and the EU with competences and self-government in several fields, including tax collection (Morgan, 2016; Navarro et al., 2014; OECD, 2011; Valdaliso, 2015). It belongs to the group of technological advanced regions in the EU, with a strong weight of the manufacturing industry: in 2016 industry accounted for $26.3 \%$ of its GDP and $20.1 \%$ of employment, percentages much higher than both the Spanish and European average. Its strong industrial base helps explaining another two characteristics: its high R\&D intensity and strong export orientation. 
This story of transformation goes hand in hand with an increasing resilience of the Basque economy towards the different economic crises the region has gone through, from the late 1970s until today (Birch et al., 2010; Cueto et al., 2017, pp. 71-73; Cuadrado \& Maroto, 2016), and can be measured indirectly by its sustained process of catching up and convergence with the EU-15, in GDP per capita terms (see Fig. 11.1). At the sector- and micro-level, Basque firms, clusters and industries have shown, too, a higher resilience than those of other Spanish regions in the last economic crisis (Cruz-Castro et al., 2018; Elola et al., 2013; González-Bravo et al., 2018; Holl \& Rama, 2016; Valdaliso et al., 2016; Valdaliso, 2020). Finally, the Basque Country scores relatively high in the quality of government index among European regions (Charron \& Lapuente, 2018) and seems to have a good level of social capital (Etxabe \& Valdaliso, 2016), two factors that increase regional resilience (Cortinovis et al., 2017).

Following previous works on this issue (Kakderi \& Tasopoulou, 2017), our aim is to examine the policy responses given to the main economic crises and structural changes the region has gone through over the last

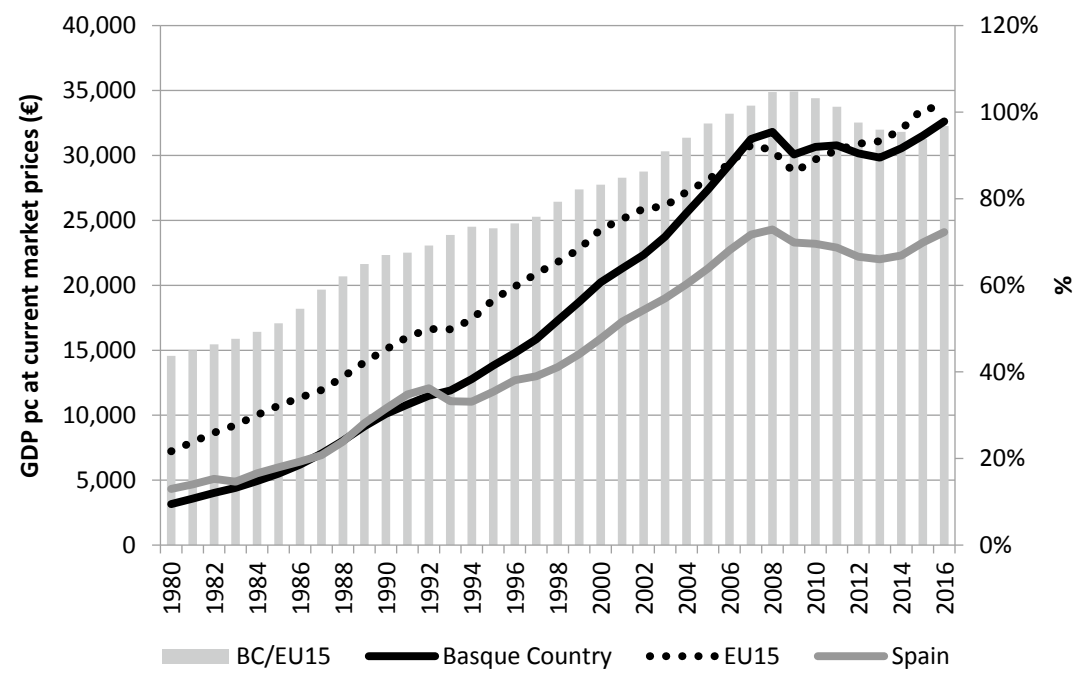

Fig. 11.1 GDP per capita in the Basque Country, Spain and the EU-15, 19802016 (Source Authors' elaboration from EUSTAT and EUROSTAT) 
40 years, the key agents involved and their impact on the subsequent regional growth path. We have considered all types of public policies, from different levels and domains, although only the most important do appear in the Table 11.1. With regard to policy measures, we have made a distinction between short-term reactive policy measures (aimed at resisting and adapting to the crisis) and mid- long-term proactive policy measures (aimed at promoting and/or coping with structural change). The first type would exert an effect on that crisis, whereas the second type could have longer lasting effects on the regional economic resilience that would be manifest, for instance, in the next economic crisis.

However, public policies are not only reactions to external shocks, but they are also embedded in policy processes and dynamics subjected to path dependence, agency and power (Mahoney \& Thelen, 2009; Pierson, 2004). In this way, the menu of policies available towards a new crisis is affected not only by the existing policy paradigm in the region, but also by its economic structure and its degree of resilience. Putting it another way, we analyse three pictures (policy responses towards three different economic crises) framed within a single movie (the policy process in the Basque region over the last 40 years).

As important as the policy responses in our chapter are, the key agents involved in the policy process and their behaviour are the primary unit of analysis. The main agents in our case study are the regional government, a few institutional entrepreneurs, and some RTOs (Regional Technology Organizations) and firms. Regarding their behaviour, we follow the typology of Bristow and Healy (2014): they may anticipate, react or transform. We have also attempted to describe the coordination mechanisms of this policy community: networks, coalitions, leaders and leadership.

It should be noticed, nevertheless, that there are other factors that may have an impact on the regional growth path not considered here, such as the evolution of global demand. However, this is a kind of exogenous, taken for granted, variable that affects all the regions within a given economic area with similar levels of openness.

According to the evolution of GDP and unemployment, we identify three major economic crises that can also be observed in other European regions (Martin, 2012): that of 1976-1983, the 1992-1994 years, and the last economic recession of 2008-2015 (see Fig. 11.2). The region has also had to cope with three structural changes: (i) the deindustrialization process that started with the first economic crisis, although only 


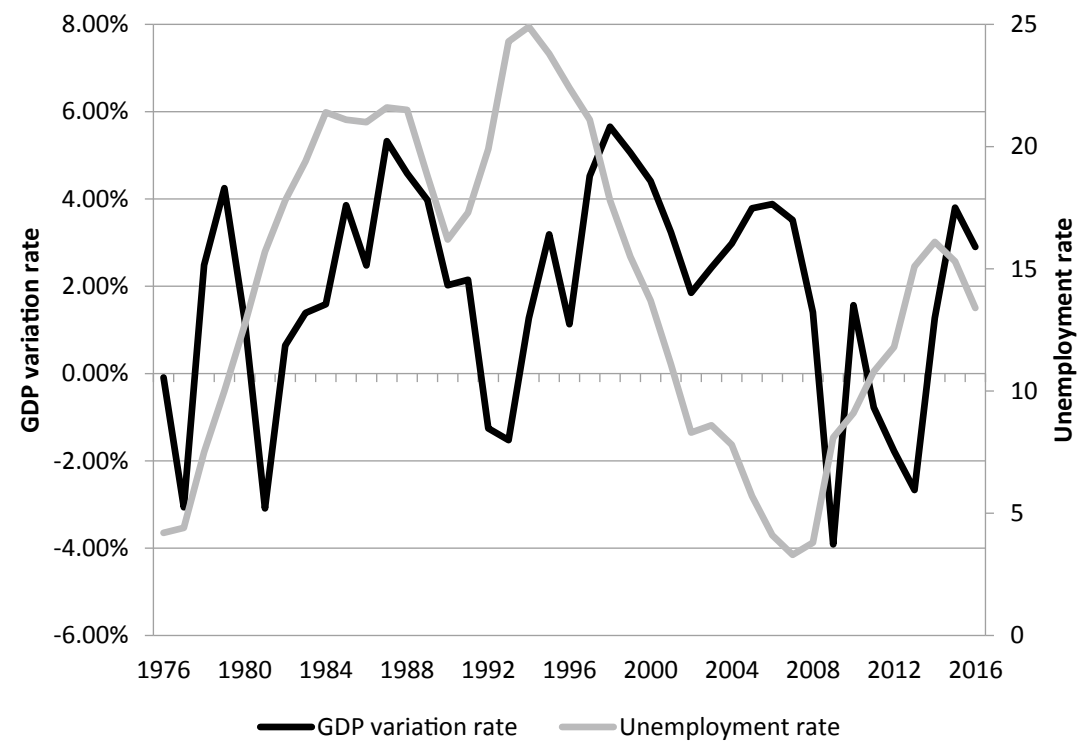

Fig. 11.2 GDP variation and unemployment rates in the Basque Country, 1976-2016 (Source Authors' own elaboration from EUSTAT and Caja Laboral Popular [1987] for unemployment, and from De la Fuente [2017] for GDP)

during the last one governments at the different levels-from the European Commission to regional governments-have become fully aware of its implications for the entire economy; (ii) the transition from a closed to an open economy during the 1980s; and (iii) the transition from a factor-driven to a knowledge-driven economy, during the 1980s and 1990s.

Table 11.1 summarizes the history of economic crises, structural changes and policy responses in the Basque Country over the last 40 years. We briefly indicate in the second column their main consequences for the region. The third column presents the policy responses during the crisis and/or in the following years and, if they existed, the government agendas to cope with them. Column fourth identifies the most important agents behind those policies in every crisis; column fifth, the governance mechanism and the dominant behaviour of the key agents; and column sixth, the perceived impact of those policies on the region's subsequent growth and policy paths. 
E. MAGRO ET AL.

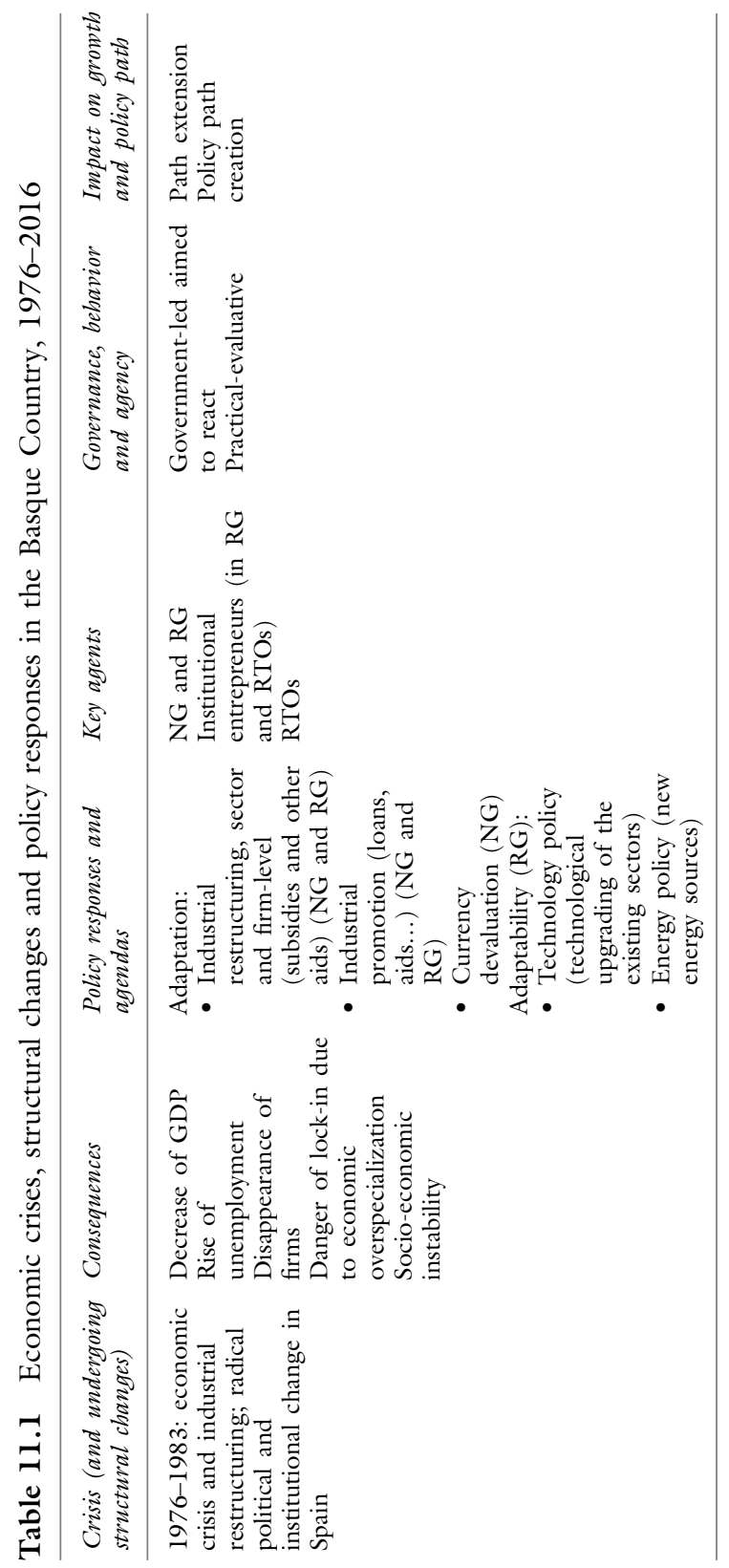




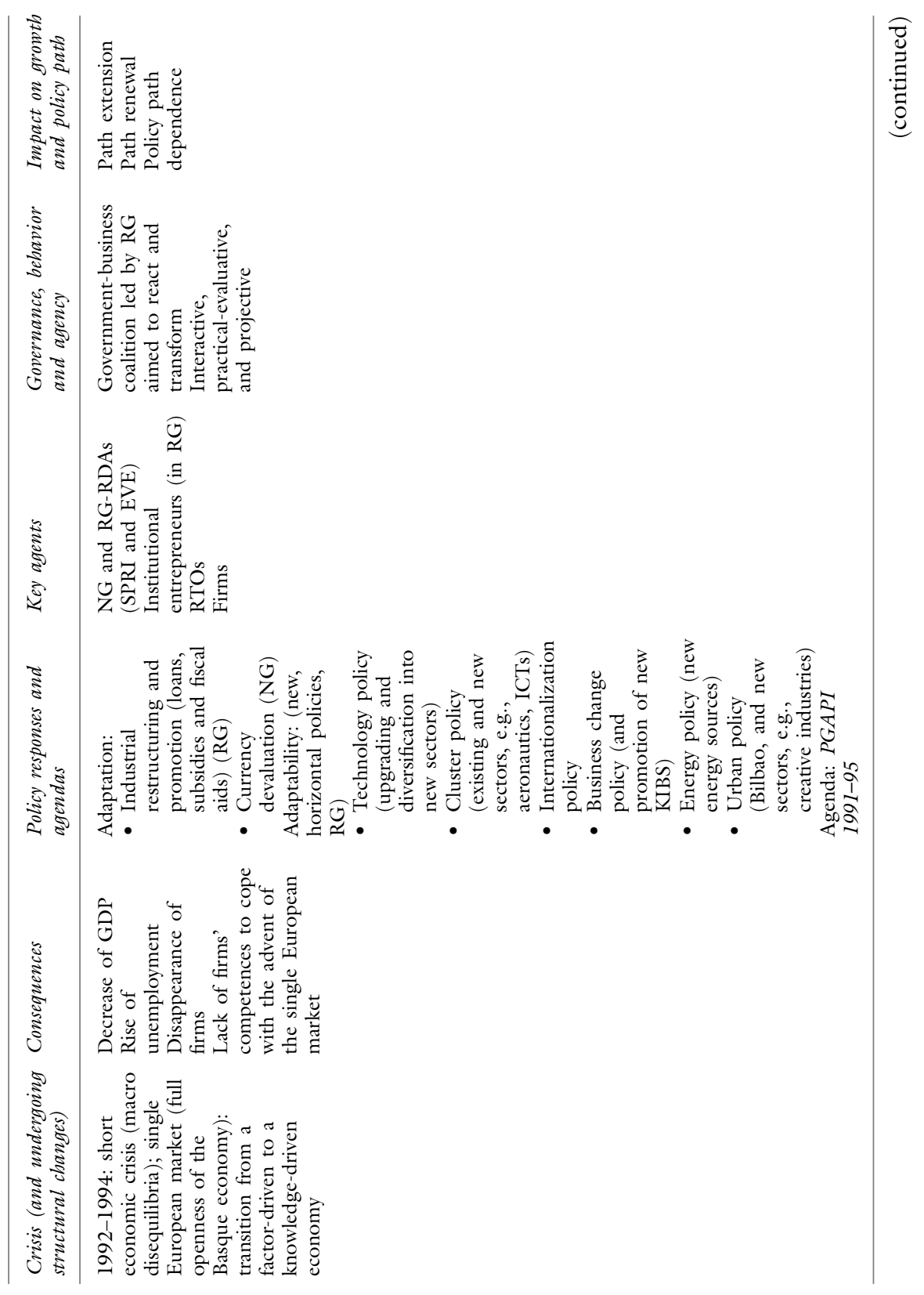




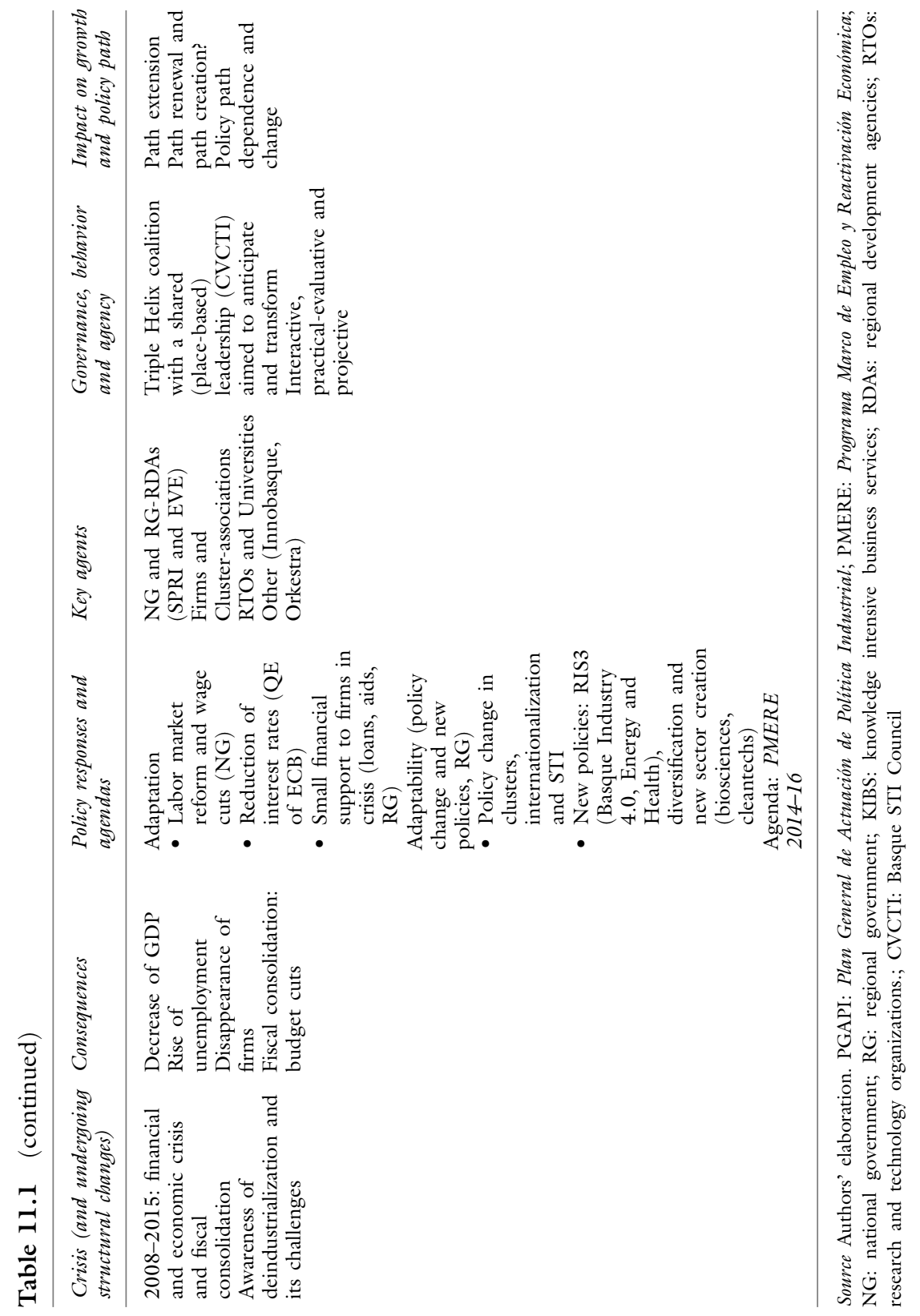


The first economic crisis (1976-1983) hit hardest an economy such as that of Spain, highly protected to foreign competition and scarcely competitive. Old industrial regions such as the Basque Country, which had overspecialized in a small group of sectors (iron \& steel, metallic products, machinery and transport material and equipment), faced a real danger of lock-in. To make matters worse, the crisis went hand in hand with a deep and radical political change in Spain, which increased institutional uncertainty, labour mobilization and, in the Basque region, a significant rise of terrorist activities that targeted, among other groups, businessmen and managers. The crisis resulted in the disappearance of hundreds of firms and the loss of thousands of jobs, particularly in the industry (Aranguren et al., 2012; Valdaliso, 2015).

The policy responses adopted were of two types and were led by two government levels. The national government, along with some macroeconomic measures (such as currency devaluation), put in motion industrial restructuring and promotion programmes with the aim of resisting and adapting to the crisis. The Basque government, which had been created from scratch in 1980 (in the context of the new political system in Spain, which gave considerable autonomy and competences to regional governments), adopted some complementary measures of industrial restructuring and promotion over the 1980s, to help the existing sectors to resist, but also started new policies in the fields of technology and energy aimed towards improving adaptability. Behind those new policies was a small group of institutional entrepreneurs that came from the industrial sector and/or a few RTOs, led by the Ministry of Industry, Javier García-Egocheaga. Their dominant behaviour in those years was reactive rather than proactive. In relation to the latter, it was about doing the same things (continuity), but in a more efficient way (exploitation, according to March, 1991). During the early 1980s, the first regional government built up an institutional architecture and started a policy path that became reinforced afterwards (Valdaliso et al., 2014).

The second economic crisis (1992-1994) was shorter and more focused but also brought about a decrease in GDP and a significant rise of unemployment. In spite of the economic recovery of the second half of the 1980s and the positive effects of Spain's integration into the EEC (European Economic Community), Basque firms still had several weaknesses that put them in a difficult situation to cope with the new single European market, the most important structural change perceived as such by all the agents in the region. Like in the previous crisis, currency 
devaluation and industrial restructuring and promotion programs were adopted. However, the Basque government took that crisis as an opportunity space to adopt a broad agenda for change and transformation, to help Basque firms to cope with the advent of the single European market but also to facilitate the transition from a factor-driven to a knowledge-driven economy, centred on industry. In fact, the PGAPI's 1991-1995, led by the Vice-President Jon Azua, who acted as a true institutional entrepreneur (with a lot of political power), explicitly formulated those challenges and envisaged a wide scope of policy measures with the aim of improving what it already existed (path extension) and encouraging the diversification of the Basque economy into new related sectors such as aeronautics, telecommunications, information technologies and knowledge intensive business services (path renewal) (Aranguren et al., 2012; Valdaliso, 2015). The PGAPI agenda reinforced the system's institutional architecture and the policy path taken in the 1980s although allocated some space for change, mainly through layering (Mahoney \& Thelen, 2009), e.g., the creation of new institutions and organizations in the system, such as cluster-associations (Valdaliso et al., 2014), alongside existing ('old') arrangements. The regional government continued leading the policy process, although it attempted to get private business involved through the creation of public-private organizations and even by recruiting some individuals from the private sector to political posts in the government.

The policy responses to this crisis and to the structural changes the Basque economy had to cope with traced a policy path and a strategy for economic development that became reinforced over the sustained economic prosperity that lasted up to 2007. In a context of growing budget and plenty of resources, new institutions and organizations (Universities, new RTOs, Innobasque and other agencies, Orkestra, etc.) were added to the system, which became increasingly dense and complex; and the diversification efforts continued towards new sciencebased sectors such as biosciences, nano- and micro-technologies, with the aim of driving the Basque economy towards a new, knowledge-driven, growth path (Magro et al., 2014; Valdaliso, 2015; Valdaliso et al., 2014). Alongside the regional government and its RDAs, firms and the existing RTOs, new agents such as cluster associations, universities and new RTOs, alongside new government agencies played increasing prominent roles. Policy learning and experimentation helped to transform the system's governance, which became less hierarchical and more participative. 
By its length and intensity, the last economic crisis was as important as that of the early 1980s. It also brought about a fiscal consolidation that resulted in considerable budget cuts by the national and regional governments. The macroeconomic policy responses were adopted by the European Central Bank and by the national government (labour market reform). The regional government provided, in the first years of the crisis, financial support to help firms to resist, although not to the same degree when compared to previous crises. The successive Basque governments maintained the broad lines of their sustained economic strategy and policy, strongly focused on industry as the key sector of the Basque economy, but now adopted to the new policy paradigm of smart specialization (RIS3). In this sense, the strong and strategic bet on industry as the core sector of the Basque economy, sustained from the 1980s, allowed the Basque country to resist better-in a European perspective-the danger of deindustrialization with one of the highest shares of industry over GDP of all the European regions (NUTS2). Like in the previous crisis, the regional government saw it as an opportunity to initiate a process of change in some long-sustained policies (clusters, STI [Science, Technology and Innovation], internationalization) and in the institutional architecture and network of policy agents. The budget cuts forced the regional government to concentrate its economic diversification efforts towards three strategic priorities-Basque Industry 4.0, Energy and Health-and to re-design the existing network of cluster-associations and scientific and technological agents (Morgan, 2016; Navarro, 2015).

Overall, policy responses attempted to improve the adaptability of the regional economy and its agents to the new scenario facilitating change and to some extent, anticipating new challenges. The process of policy learning in the previous period and the advances registered towards a more horizontal and participative policy process made possible now a new system's governance with a shared leadership, supported by a triple helix coalition (integrated by the government, RTOs and universities, and firms and cluster-associations), of which the CVCTI or the steering groups of RIS3 priorities were clear proofs.

\section{Discussion AND Conclusions}

This chapter emphasizes the role of institutions, especially policy, and agency in shaping regional resilience, understood as the capability of 
regions to resist, adapt, respond recover and or/renew from a shock (Martin, 2012). Adaptation and adaptability processes contribute to resilience as a regional capability to cope with both economic crises and structural changes and therefore need to be studied following a historical perspective (Henning, 2019). This is precisely our contribution with the long-term and holistic perspective we have taken when discussing the Basque case, where we distinguish three main episodes and disentangle the role of policy measures and agency to foster adaptation in the shortterm and adaptability in the medium-long term, aiming at creating new regional growth paths as a sign of resilience.

The case effectively shows how policy shapes resilience, but it also highlights that those policy responses are neither single nor simple. Complexity in policy responses is also discussed by innovation studies and sustainable transitions literature under the policy-mix concept (Flanagan et al., 2011; Rogge \& Reichardt, 2016) but this chapter goes further by highlighting the importance of combinatorial policy processes (namely adaptive, adaptability or exploitation and exploration), following an evolutionary economic geography view. This supports March's (1991) assumption of the importance of maintaining a balance between exploration and exploitation within a system perspective. Indeed, in this case, the combination of different responses in the three crisis moments shows how policy is context and time specific and denotes path dependence of previous policy paths and influence from governance and power relationships within and beyond the region. Thus, in the three analysed periods policy measures have been combined to foster both adaptation by implementing urgent measures to the shocks and policies aiming at contributing to adaptability have been implemented. It is also important to highlight that the measures directed to foster adaptability over time have led to an evolutionary policy process. For example, technology policy in the first period facilitated the transition towards a knowledge-driven economy in the second period, and this constituted the roots for a strong smart specialization strategy (Foray, 2014) in the last one. These policy responses have facilitated the creation and renewal of regional growth paths coping not only with economic crises but also with economic structural changes.

The case also demonstrates the importance of other types of institutions, such as governance arrangements and agency in regional resilience. It is clear that agency shapes institutions, including policy (Uyarra et al., 2017). The relationships established from the very beginning among 
different types of actors within the region (regional government, RTOs, firms) and beyond the region (especially national and EU governments) have shaped policy responses. However, the case shows how regional institutions and agency have been the most important drivers for regional adaptability and therefore for regional resilience. This highlights the importance of regional capabilities for resilience, in line with the assumption of Boschma (2015) who underlined the importance of the resilience of different units of analysis within regions (individuals, networks, etc). It is also important to acknowledge the role of institutional entrepreneurs (DiMaggio, 1988) from the very beginning, especially from the regional government. Despite its highly interventionist nature, the regional government facilitated the development of governance mechanisms within the region over time, thus leading to collective agency and shared, place-based leadership (Bailey et al., 2010), which in turn catalyzed regional path renewal and path creation.

In addition, in terms of agency the analysis shows an evolutionary path. The case illustrates how determinant the adoption from the very beginning of a practical-evaluative (approach to cope with emerging demands) is, and especially as the regional government was created from scratch in 1980 and therefore had no pre-existing regional institutional arrangements. But what is also more relevant is that since the first crisis episode the three dimensions of agency were present in the region. Thus, in the 1990s, the interactive dimension was present as the policy path taken in the 1980s was reinforced; but a practical-evaluative approach was also identified in the form of a diagnosis of the Basque economy and the possibilities and measures to take. Finally, the projective dimension arises as relevant because for the first time a sort of vision of the Basque economy is proposed. The projective dimension continued in the last crisis, with the implementation of a regional smart specialization strategy based on related variety and the creation of new growth paths. In addition, the case also denotes the importance of bricolage (Garud \& Karnøe, 2003) in times of crises and the ability of regional government to transfer models, practices and experiences from elsewhere to the region (Navarro et al., 2014). All these elements can be signalled as constituents of place-based leadership (Bailey et al., 2010).

Recognizing the complexity of regional resilience and the lack of a single recipe for all territories, the chapter shows the importance of evolutionary processes in both policy measures and agency for regional path development. Furthermore, the chapter highlights a co-evolutionary 
process (Gong \& Hassink, 2019) between policy and agency as both show a reciprocal influence. Policy seen as an evolutionary path-dependent process shapes agency and at the same time, agency influences policy responses. Therefore, there is not a linear causality between policy and agency but a nested institutional context in which the different factors co-evolve and co-determine each other.

Finally, learnings from this chapter could also inform the (organizational) resilience literature more broadly. First, as regards the importance of combining ex ante and ex post processes (adaptability and adaptation) and keeping a balance between exploration and exploitation processes for resilience. Second, in relation to the importance of agency and leadership for resilience. And finally, in terms of the interplay of institutions (organizations and formal and informal rules of the game) and actors in a co-evolving process of change, which is time and context specific and can lead to mutual reinforcement or mutual weakening outcomes, as described by Gong and Hassink (2019).

Acknowledgements The authors acknowledge financial support from MINECO HAR2016-76198-P (AEI/FEDER, UE), and from the Basque Government Department of Education (IT897-16).

\section{REFERENCES}

Annarelli, A., \& Nonino, F. (2016). Strategic and operational management of organizational resilience: Current state of research and future directions. Omega, 62, 1-18.

Aranguren, M. J., Magro, E., Navarro, M., \& Valdaliso, J. M. (2012). Estrategias para la construcción de ventajas competitivas regionales. El caso del País Vasco. Marcial Pons.

Bailey, D., Bellandi, M., Caloffi, A., \& De Propris, L. (2010). Place-renewing leadership: Trajectories of change for mature manufacturing regions in Europe. Policy Studies, 31(4), 457-474.

Bailey, D., \& Berkeley, N. (2014). Regional responses to recession: The role of the West Midlands Regional Taskforce. Regional Studies, 48(11), 1797-1812.

Battilana, J., \& D'aunno, T. (2009). Institutional work and the paradox of embedded agency. Institutional Work: Actors and Agency in Institutional Studies of Organizations, 31, 58.

Baumgartner, F. R. (2013). Ideas and policy change. Governance: An International Journal of Policy, Administration, and Institutions, 26(2), 239-258. 
Billington, M. G., Karlsen, J., Mathisen, L., \& Pettersen, I. B. (2017). Unfolding the relationship between resilient firms and the region. European Planning Studies, 25(3), 425-442.

Birch, K., Mackinnon, D., \& Cumbers, A. (2010). Old industrial regions in Europe: A comparative assessment of economic performance. Regional Studies, 44(1), 35-53.

Boinand, A., \& Van Eeten, M. J. G. (2014). The resilient organization: A critical appraisal. Public Management Review, 15(3), 429-445.

Boschma, R. (2015). Towards and evolutionary perspective on regional resilience. Regional Studies, 49(5), 733-751.

Bristow, G., \& Healy, A. (2014). Regional resilience: An agency perspective. Regional Studies, 48(5), 923-935.

Brooks, C. (2017). Governance, civic leadership and resilience. In N. Williams \& T. Vorley (Eds.), Creating resilient economies: Entrepreneurship, growth and development in uncertain times (pp. 125-141). Edward Elgar.

Campbell, J. L. (2010). Institutional reproduction and change. In G. Morgan, J. L. Campbell, C. Crouch, O. K. Pedersen, \& R. Whitley (Eds.), The Oxford handbook of comparative institutional analysis. Oxford University Press.

Charron, N., \& Lapuente, V. (2018). Quality of government in EU regions: Spatial and temporal patterns. QoG Working Paper Series, 2018(1), 1.

Cortinovis, N., Xiao, J., Boschma, R., \& van Oort, F. (2017). Quality of government and social capital as drivers of regional diversification in Europe. The Journal of Economic Geography, 17, 1179-1208.

Crescenzi, R., Luca, D., \& Milio, S. (2016). The geography of the economic crisis in Europe: National macroeconomic conditions, regional structural factors and short-term economic performance. Cambridge Journal of Regions, Economy and Society, 9(1), 13-32.

Croenewegen, J., \& van der Steen, M. (2007). The evolutionary policy maker. Journal of Economic Issues, 41(2), 351-358.

Cruz-Castro, L., Holl, A., Rama, R., \& Sanz-Menendez, L. (2018). Economic crisis and company R\&D in Spain: Do regional and policy factors matter? Industry and Innovation, 25(8), 729-751.

Cuadrado, J. R., \& Maroto, A. (2016). Unbalanced regional resilience to the economic crisis in Spain: A tale of specialisation and productivity. Cambridge Journal of Regions, Economy and Society, 9, 153-178.

Cueto, M. B., Mayor, M., \& Suárez, P. (2017). La resiliencia de las regiones españolas después de la gran recesión. Consejo Económico y Social del Principado de Asturias.

David, L. (2018). Agency and resilience in the time of regional economic crisis. European Planning Studies, 26(5), 1041-1059. 
DiMaggio, P. (1988). Interest and agency in institutional theory. In L. Zucker (Ed.), Institutional patterns and culture (pp. 3-22). Cambridge, MA: Ballinger.

Elola, A., Parrilli, M. D., \& Rabelloti, R. (2013). The resilience of clusters in the context of increasing globalization: The Basque wind energy value chain. European Planning Studies, 21(7), 989-1006.

Emirbayer, M., \& Mische, A. (1998). What is agency? American Journal of Sociology, 103(4), 962-1023.

Eraydin, A. (2016). The role of regional policies along with the external and endogenous factors in the resilience of regions. Cambridge Journal of Regions, Economy and Society, 9(1), 217-234.

Etxabe, I., \& Valdaliso, J. M. (2016). Measuring structural social capital in a cluster policy network: Insights from the Basque Country. European Planning Studies, 24(5), 884-903.

Evans, R., \& Karecha, J. (2014). Staying on top: Why is Munich so resilient and successful? European Planning Studies, 22(6), 1259-1279.

Evenhuis, E. (2017a). New directions in researching regional economic resilience and adaptation. Geography Compass, 11(11), e12333.

Evenhuis, E. (2017b). Institutional change in cities and regions: A path dependency approach. Cambridge Journal of Regions, Economy and Society, 10, 509-526.

Flanagan, K., \& Uyarra, E. (2016). Four dangers in innovation policy studiesAnd how to avoid them. Industry and Innovation, 23(2), 177-188.

Flanagan, K., Uyarra, E., \& Laranja, M. (2011). Reconceptualising the 'policy mix' for innovation. Research Policy, 40, 702-713.

Foray, D. (2014). Smart specialisation: Opportunities and challenges for regional innovation policy (pp. 25-30). Routledge.

Foray, D., Goddard, J., Goenaga, X., Landabaso, M., McCann, P., Morgan, K., Nauwelaers, C., \& Ortega-Argilés, R. (2012). Guide to research and innovation strategies for smart specialisations (RIS3). European Commission, Brussels.

Fratesi, U., \& Rodríguez-Pose, A. (2016). The crisis and regional employment in Europe: What role for sheltered economies? Cambridge Journal of Regions, Economy and Society, 9(1), 33-57.

Garud, R., \& Karnøe, P. (2001). Path creation as a process of mindful deviation. In R. Garud \& P. Karnøe (Eds.), Path dependence and creation (pp. 1-38). NJ, Mahwah: Lawrence Earlbaum Associates.

Garud, R., \& Karnøe, P. (2003). Bricolage versus breakthrough: Distributed and embedded agency in technology entrepreneurship. Research Policy, 32(2), 277-300.

Garud, R., Kumaraswamy, A., \& Karnøe, P. (2010). Path dependence or path creation? Journal of Management Studies, 47(4), 760-774. 
Gingrich, J. (2015). Varying costs to change? Institutional change in the public sector. Governance: An International Journal of Policy, Administration, and Institutions, 28(1), 41-60.

Gong, H., \& Hassink, R. (2019). Co-evolution in contemporary economic geography: Towards a theoretical framework. Regional Studies, 53(9), 1344-1355.

González-Bravo, M., López, S., \& Valdaliso, J. M. (2018). Coping with economic crises: Cluster associations and firm performance in the Basque Country. In F. Belussi \& J. L. Hervás-Oliver (Eds.), Cluster advantage and firm performance (pp. 245-262). Springer.

Grabher, G. (1993). The weakness of strong ties: The lock-in of regional development in the Rhur area. In G. Grabher (Ed.), The embedded firm: On the socioeconomics of industrial networks (pp. 255-277). Routledge.

Grillitsch, M., \& Sotarauta, M. (2020). Trinity of change agency, regional development paths and opportunity spaces. Progress in Human Geography, 44(4), 704-723.

Grillitsch, M., \& Sotarauta, M. (2018). Regional growth paths: From structure to agency and back (Papers in Innovation Studies 2018/01, CIRCLE).

Henning, M. (2019). Time should tell (more): Evolutionary economic geography and the challenge of history. Regional Studies, 53(4), 602-613.

Henning, M., Stam, E., \& Wenting, R. (2013). Path dependence research in regional economic development: Cacophony or knowledge accumulation? Regional Studies, 47(8), 1348-1362.

Holl, A., \& Rama, R. (2016). Persistence of innovative activities in times of crisis: The case of the Basque Country. European Planning Studies, 24(10), $1863-1883$.

Isaksen, A. (2015). Industrial development in thin regions: Trapped in path extension? Journal of Economic Geography, 15(3), 585-600.

Kakderi, C., \& Tasopoulou, A. (2017). Regional economic resilience: The role of national and regional policies. European Planning Studies, 25(8), 1435-1453.

Kay, A. (2006). The dynamics of public policy: Theory and evidence. Edward Elgar. Kingdon, J. W. (1984). Agendas, alternatives, and public policies. Little Brown.

Landabaso, M. (2012). What public policies can and cannot do for regional development. In P. Cooke, M. D. Parrilli, \& J. L. Curbelo (Eds.), Innovation, global challenge, and territorial resilience (pp. 364-381). Edward Elgar.

Lawrence, T. B., \& Suddaby, R. (2006). Institutions and institutional work. In The Sage handbook of organization studies (p. 215). Sage.

Magro, E., Navarro, M., \& Zabala-Iturriagagoitia, J. M. (2014). Coordinationmix: The hidden face of STI policy. Review of Policy Research, 31(5), 367-389.

Maguire, S., Hardy, C., \& Lawrence, T. B. (2004). Institutional entrepreneurship in emerging fields: HIV/AIDS treatment advocacy in Canada. The Academy of Management Journal, 47, 657-79. 
Mahoney, J., \& Thelen, K. (2009). A theory of gradual institutional change. In J. Mahoney \& K. Thelen (Eds.), Explaining institutional change: Ambiguity, agency, and power. Cambridge University Press.

March, J. G. (1991). Exploration and exploitation in organizational learning. Organization Science, 2(1), 71-87.

Martin, R. (2010). Rethinking regional path dependence: Beyond lock-in to evolution. Economic Geography, 86(1), 1-27.

Martin, R. (2012). Regional economic resilience, hysteresis and recessionary shocks. Journal of Economic Geography, 12, 1-32.

Martin, R., \& Sunley, P. (2006). Path dependence and regional economic evolution. Journal of Economic Geography, 6(4), 395-437.

Martin, R., \& Sunley, P. (2015). On the notion of regional economic resilience: Conceptualization and explanation. Journal of Economic Geography, 15, 1-42.

Martin, R., Sunley, P., Gardiner, B., \& Tyler, P. (2016). How regions react to recessions: Resilience and the role of economic structure. Regional Studies, $50(4), 561-585$.

Morgan, K. (2016). Collective entrepreneurship: The Basque model of innovation. European Planning Studies, 24(8), 1544-1560.

Nauwelaers, C., \& Wijtnes, R. (Eds.). (2008). Innovation policy in Europe: Measurement and strategy. Edward Elgar Publishing.

Navarro, M. (2015). Las estrategias territoriales para la transformación productiva. Reflexión desde el caso del País Vasco. Icade. Revista de las Facultades de Derecho y Ciencias Económicas y Empresariales, 96, 75-104.

Navarro, M., Valdaliso, J. M., Aranguren, M. J., \& Magro, E. (2014). A holistic approach to regional strategies: The case of the Basque Country. Science and Public Policy, 41, 532-547.

Neffke, F., Henning, M., \& Boschma, R. (2011). How do regions diversify over time? Industry relatedness and the development of new growth paths in regions. Economic Geography, 87(3), 237-265.

OECD. (2011). OECD reviews of regional innovation: Basque Country, Spain. OECD.

Pierson, P. (2004). Politics in time: History, institutions, and social analysis. Princeton University Press.

Pugalis, L., Gray, N., \& Townsend, A. (2017). The resilience of growth strategies. In N. Williams \& T. Vorley (Eds.), Creating resilient economies: Entrepreneurship, growth and development in uncertain times (pp. 160-174). Edward Elgar.

Rogge, K. S., \& Reichardt, K. (2016). Policy mixes for sustainability transitions: An extended concept and framework for analysis. Research Policy, 45(8), $1620-1635$. 
Simmie, J., \& Martin, R. (2010). The economic resilience of regions: Towards an evolutionary approach. Cambridge Journal of Regions, Economy and Society, $3,27-44$.

Steen, M. (2016). Reconsidering path creation in economic geography: Aspects of agency, temporality and methods. European Planning Studies, 24(9), 16051622.

Streeck, W., \& Thelen, K. (2005). Introduction: Institutional change in advanced political economies. In W. Streeck \& K. Thelen (Eds.), Beyond continuity: Institutional change in advanced political economies (pp. 3-39). Oxford University Press.

Tomlinson, P. R., \& Branston, J. R. (2014). Turning the tide: Prospects for an industrial renaissance in the North Staffordshire ceramics industrial district. Cambridge Journal of Regions, Economy and Society, 7(3), 489-507.

Uyarra, E., Flanagan, K., Magro, E., Wilson, J. R., \& Sotarauta, M. (2017). Understanding regional innovation policy dynamics: Actors, agency and learning. Environment and Planning C: Politics and Space, 35(4), 559-568.

Uyarra, E., \& Ramlogan, R. (2012). Cluster policy: A review of the evidence. National Endowment for Science, Technology and the Arts (NESTA), University of Manchester.

Uyarra, E., Zabala-Iturriagagoitia, J. M., Flanagan, K., \& Magro, E. (2020). Public procurement, innovation and industrial policy: Rationales, roles, capabilities and implementation. Research Policy, 49(1), 103844.

Valdaliso, J. M. (2015). The Basque Country: Past trajectory and path dependency in policy- and strategy-making. In J. M. Valdaliso \& J. R. Wilson (Eds.), Strategies for shaping territorial competitiveness. Routledge.

Valdaliso, J. M. (2020). Accounting for the resilience of the machine tool industry in Spain (c. 1960-2015). Business History, 62(4), 637-662.

Valdaliso, J. M., Elola, A., \& Franco, S. (2016). Do clusters follow the industry life cycle? Diversity of cluster evolution in old industrial regions. Competitiveness Review, 26(1), 66-86.

Valdaliso, J. M., Magro, E., Navarro, M., Aranguren, M. J., \& Wilson, J. R. (2014). Path dependence in policies supporting smart specialization strategies. European Journal of Innovation Management, 17(4), 390-408.

Valdaliso, J. M. \& Wilson, J. R. (Eds.). (2015). "Introduction", Strategies for shaping territorial competitiveness (pp. 1-15). Routledge.

Webber, D. J., Healy, A., \& Bristow, G. (2018). Regional growth paths and resilience: A European analysis. Economic Geography, 98(4), 355-375.

Witt, U. (2003). Economic policy making in evolutionary perspective. Journal of Evolutionary Economics, 13, 77-94. 
Open Access This chapter is licensed under the terms of the Creative Commons Attribution 4.0 International License (http://creativecommons.org/licenses/ by $/ 4.0 /$ ), which permits use, sharing, adaptation, distribution and reproduction in any medium or format, as long as you give appropriate credit to the original author(s) and the source, provide a link to the Creative Commons license and indicate if changes were made.

The images or other third party material in this chapter are included in the chapter's Creative Commons license, unless indicated otherwise in a credit line to the material. If material is not included in the chapter's Creative Commons license and your intended use is not permitted by statutory regulation or exceeds the permitted use, you will need to obtain permission directly from the copyright holder.

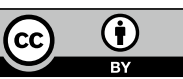

